\title{
DIAGNOSIS OF MUSCULOSKELETAL COMPLAINTS IN THE ELDERLY DURING THE COVID 19 PANDEMIC
}

\author{
Ike Anisa ${ }^{1}$, Amalia Solichati Rizqi², Rima Yunita Sari ${ }^{3}$, \\ Yudha Wahyu Putra ${ }^{4}$ \\ Universitas Widya Dharma Klaten $n^{1,2,3,4}$ \\ Ikeamalia212@gmail.com
}

\begin{abstract}
Background Corona Virus Disease 2019 (COVID-19) is a large family of viruses that cause diseases ranging from mild to severe, such as the common cold or the common cold and serious diseases such as MERS and SARS. The World Health Organization (WHO) has declared a public health emergency of international concern to coordinate the international response to the disease. The COVID-19 pandemic has had a huge impact on the world, one of which is Indonesia. Covid 19 has had many impacts in various sectors. The purpose of this study was to diagnose musculoskeletal complaints in the elderly during the COVID-19 pandemic using a manual muscle testing approach and a visual analog scale. The method in this research is analytical descriptive research, which describes the condition of musculoskeletal complaints in the elderly during the covid 19 pandemic. The subjects are the people of Tanjungan Village, Wedi District, Klaten Regency by looking at musculoskeletal complaints using a manual muscle testing approach and visual analog scale. The results showed that the average Manual Muscle testing for the 60-69 year age group a was 4.25, the male 4.5 and the female 4. The Visual Analog scale value for the age group 60-69 years was 2, the age 70-79 was 4, male gender 2 and female gender 4 . Conclusion Older people over 60 years have a risk of musculoskeletal disorders during the COVID-19 pandemic.
\end{abstract}

Keywords: Visual Analog Scale, Manual Muscle Testing

Accepted: $25^{\text {th }}$ of January 2022

Correspondence author : Ike Anisa, Universitas Widya Dharma Klaten, Indonesia.

E-Mail: Ikeamalia212@gmail.com

DOI http://dx.doi.org/10.31851/hon.v5i1.7132 dc

\section{(c) (i) (2)}

Jurnal Halaman Olahraga Nusantara licensed under a Creative Commons Attribution-ShareAlike 4.0 International License

\section{INTRODUCTION}

Health is the demand of every individual (Putra YW \& Rizqi AS,2020 ). Severe acute respiratory syndrome coronavirus 2 (SARS-CoV-2) is a new coronavirus that emerged in 2019 and causes coronavirus disease 2019 (COVID19 (Thomas P et al, 2020. Corona Virus Disease 2019 (COVID-19) is a group of viral viruses that cause mild or severe illness, such as the common cold or cold and severe diseases such as SARS and MARS. This disease can be transmitted from animals to humans is called a zoonosis. Transmission can also occur through human to human. Until now, the process of transmitting Covid 19 is still not 
known for certain, there are a lot of opinions that have sprung up, including the virus being transmitted from animals to humans, this is based on the assumption that there are many cases of Covid 19 in Wuhan. The World Health Organization (WHO) issued a statement that there was an international emergency due to the Covid 19 virus. The impact of this virus was felt in the world, which affects every aspect of life and all sectors in the world (Liviana et al, 2020). Humans infected with the virus will show signs of respiratory tract infections ranging from flu to more serious ones, such as Middle East Respiratory Syndrome (MERS) and Severe Acute Respiratory Syndrome (SARS). (Nasution N H \& Hidayah A , 2021)

The phenomenon of a new outbreak called Covid-19 originating from Wuhan, China continues to increase its victims (Wahidah et al,2020). Keeping a distance in interacting in society makes it a necessity because of the Covid 19 virus pandemic. The above is necessary to maintain health in the community, more and more people interact with each other in the community, especially because of interactions that do not pay attention to health protocols. the spread of the Covid 19 virus is getting faster, this is what makes a person susceptible to the Covid 19 virus (Widyanigrum et al, 2020)

Health status is the main pillar in improving the quality of human resources along with education and economy, so that it is expected to create strong, productive and capable human resources to compete in all the challenges that will be faced (Bayu WI et al ,2021). According to the World Health Organization (WHO) people who do not do physical activity are one of the causes of death, the fourth highest mortality data globally is $6 \%$, which is due to not doing physical activity. Physical activity in Indonesia according to the 2018 Riskesdas Basic Health Research data is still very lacking, namely <50\% (33.5\%). The COVID-19 pandemic causes changes in attitudes and behavior that affect physical activity that can affect a person's musculoskeletal ability (Nurmidin et al, 2020) 
Musculoskeletal disorders (MSDs) are disorders of the musculoskeletal system where these disorders cause pain due to damage to nerves or blood vessels that can affect the body, both the upper and lower extremities. The upper extremities that can experience pain, for example, are the cranial, cervical, shoulder and elbow parts. Lower extremities that can experience pain such as the lumbar, hip, knee or ankle. According to the World Health Organization, disorders that occur in the musculoskeletal system are caused by various things, these factors are individual factors, work, biomechanics and psychosocial (Mayasari, 2016)

Musculoskeletal complaints can be caused by physical or mental activity carried out by a person. Work can cause musculoskeletal disorders due to improper ergonomic positions such as positions or ways of lifting items that are not in accordance with ergonomic rules, repeated use of body strength resulting in injury to muscles, long hours of work that resulting in muscle fatigue which has an impact on musculoskeletal injuries and the presence of equipment or work equipment that is not in accordance with ergonomic rules which, when used for a long time, will result in musculoskeletal injury. When an injury occurs, a person's physical activity is reduced or cannot be carried out optimally. (Wahyono \& Saloko, 2014).

The World Health Organization states that the population of the elderly in Southeast Asia is 8\%, which is approximately 142 inhabitants. In 2050 it is estimated that the population will increase by 3 times compared to today, in 2000 the number of elderly people was $5,300,000$ people or $7.4 \%$ of the total population. In 2010 the elderly population was $24,000,000$ people or around $9.77 \%$ of the population. total population, and in 2020 the number of elderly people is $28,800,000$ or about $11.34 \%$ of the total population. In Indonesia, the number of elderly people in 2020 is estimated at $80,000,000$ souls. It is estimated that the elderly population from year to year will increase, that the increase will be high enough to match the number of children under five, which is $11 \%$ of the total 
population. Indonesia itself is currently a country with the fourth largest number of elderly people in the world. (Leni AS, 2020)

Along with increasing age, the physical and bodily functions of an elderly person also decline. The highest changes in the elderly is a change or decrease in the function of the body's sensory organs and the function of the nervous system. These changes in function will affect the neuromuscular system, the cardiovascular system, and the musculoskeletal system. When the musculoskeletal system of an elderly person decreases, the quality of physical activity will decrease due to a decrease in muscle strength or muscle flexibility. These changes will affect the physical mobility and mental strength of a person (Kurnia, 2019).

Manual Muscle Testing and Visual Analog Scale is one approach method in establishing the diagnosis of musculoskeletal complaints. Manual Muscle Testing is a method for assessing musculoskeletal disorders, which is more specific, is an assessment of muscle strength. Visual Analog Scale is one approach method in diagnosing musculoskeletal complaints, specifically the visual analog scale is a parameter in determining the value of pain felt in muscles or musculoskeletal complaints.

Based on the description above, the author wants to conduct a study entitled Diagnosing musculoskeletal complaints in the elderly during the COVID-19 pandemic with a manual muscle testing approach and a visual analog scale.

\section{METHOD}

This research is a descriptive study that aims to diagnose musculoskeletal complaints in the elderly during the COVID-19 pandemic with a manual muscle testing and visual analog scale approach. The variable in this research to be conducted is a single variable, namely musculoskeletal complaints in the elderly during the COVID-19 pandemic.

Musculoskeletal complaints, namely someone who experiences muscle, bone and joint complaints. The indicator in determining this complaint is by measuring the Manual Muscle testing and visual analoge scale. The value of Manual Muscle testing is 0 respondents cannot do any movement, the value of 1 
respondent does not move but there is muscle tone palpable, the value of 2 respondents can do the movement but is unable to fight gravity, the value of 3 can defy gravity, the value of 4 is able to defy gravity and able against minimum resistance, the value of 5 respondents is able to fight maximum resistance. The value of the Visual analoge scala has a value of 0 to 10 , with a value of 0 respondents who do not feel pain at all and a value of 10 respondents who feel very painful once able to fight maximum resistance. The Visual analogue scala value has a value of 0 to 10 , with a value of 0 respondents who do not feel pain at all and a value of 10 respondents feels very painful

Describe in detail the research method you are using. Identification of designs, methods, tools, and procedures in sufficient detail to allow other researchers to repeat the research. Mention statistical tests used in detail. Ethical considerations such as clinical trials, studies conducted that have received statements from relevant ethical committees must be mentioned

\section{RESULT AND DISCUSSION}

\section{Manual Muscle Testing results by age}

Table 1. Manual Muscle Testing Values by Age

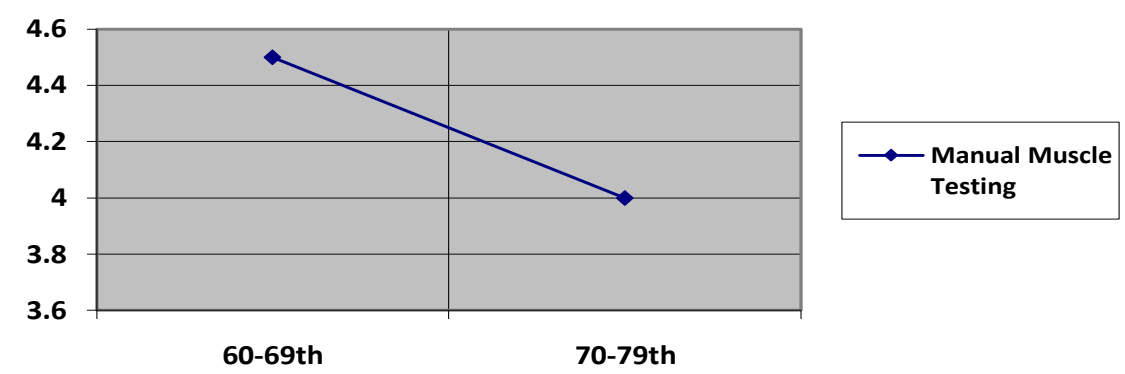

Based on the data above, it shows that the value of Manual Muscle Testing for the 60-69 year age group is 4.5 and for the 70-79 year age group is 4 .

The highest change in the elderly is a change or decrease in the function of the body's senses and the function of the nervous system. These changes in function will affect the neuromuscular system, the cardiovascular system, and the musculoskeletal system. When the musculoskeletal system of an elderly person 
decreases, the quality of physical activity will decrease due to a decrease in muscle strength or muscle flexibility. These changes will affect the physical mobility and mental strength of a person (Kurnia, 2019). Continuous physical exercise causes a reduced capacity of the body to produce strength that usually lasts longer than regular exercise (Haetami M \& Triansyah A, 2021). Amalia R \& Yudha WP tahun 2020 states that decrease in a person's level of fitness is caused by a lifestyle or habit that leads to passive activities

\section{Manual Mucle Testing Results by Gender}

Table 2. Manual Muscle Testing scores by gender
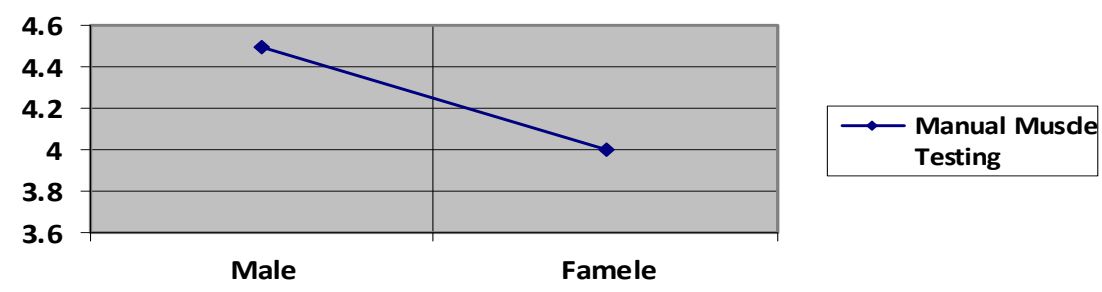

Based on the data above, it shows that the value of Manual Muscle Testing for the other sex group - male is 4.5 which means it is able to fight minimal resistance and for the female sex group is 4 which means it is able to fight minimal resistance. The above shows that Manual Muscle Testing based on both age groups is the same

Psychosocial factors at work also affect, for example, a work environment that is not conducive, interactions at work that are not good, unhealthy inter-social relationships can lead to musculoskeletal disorders. Individual factors also affect the musculoskeletal system disorders such as gender or age, men who are male tend to have muscle-skeletal strength compared to women so that the physical work of a man and a woman cannot be equated, because if it is equated it will make it easier. injury from a woman, age-related is also the same as age increases, the quality of the musculoskeletal system decreases, while individual factors related to musculoskeletal disorders (Mayasari, 2016)

\section{Results of the Visual Analogue Scale by Age}


Table 3. Visual Analog Scale Values by Age

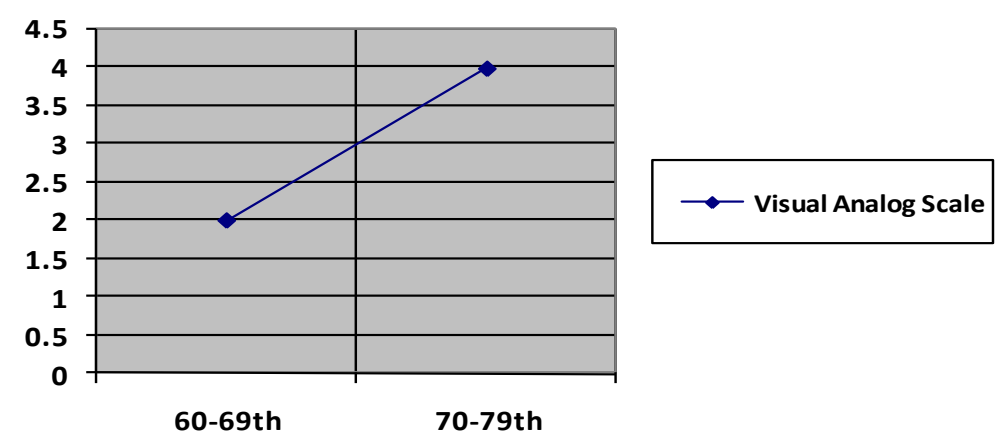

Based on the table above, it shows that the value of the visual analog scale for the 60-69 year age group is 2 and for the 70-79 year age group it is 4 .

The occurrence of pain due to the aging process (anging). The occurrence of the aging process (aging) is a physical decline which is a natural process. An elderly person will experience physiological changes in the body that lead to a decrease in physical capacity and immunity. Growing old is a condition that all living things go through. Although aging is a normal thing, the process becomes a burden for everyone so that everyone is required to maintain fitness even though the aging process continues but the pain can be slightly reduced. Human age is increasing, with increasing human age there will be changes in humans, the changes that occur can be generative where there will be changes or declines in physical, cognitive, social or. The musculoskeletal system also undergoes changes, namely bones, muscles or joints which affect the quality of the musculoskeletal system.

\section{Visual Analog Scale Results by Gender}

Table 4. Visual Analog Scale Values by Gender

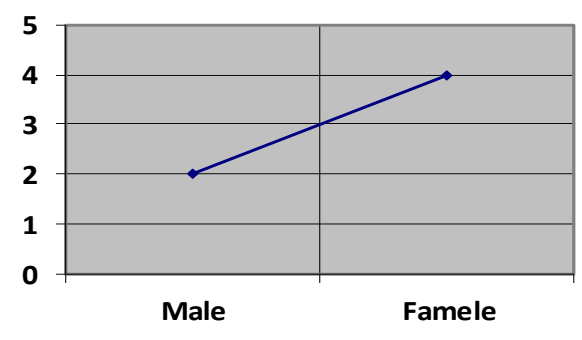

$\longrightarrow$ Visual Analog Scale 
Based on the table above, it shows that the visual analog scale value for the male sex group is 2 and the female gender group is 4 .

Gender and hormonal factors of a person can also affect the incidence of low back pain. The female sex more often experiences low back pain than the male sex. This can be due to the factor of the hormone estrogen that plays a role. Pregnancy, contraceptive use and menopause that occur in women affect the increase and decrease in estrogen levels. The increase in estrogen during pregnancy and the use of contraception causes an increase in the hormone relaxin. Increased levels of the hormone relaxin can cause weakness in the joints and ligaments, especially in the waist area. In addition, the menopause process can also cause bone density to decrease due to a decrease in the hormone estrogen, allowing for low back pain.

One of the changes that occur in the elderly with physical decline, where there is a change in the flexibility and anatomical shape of the muscles that cause muscle atrophy in the elderly where the muscle fibers will shrink and the calcium in the muscles will decrease. The above causes difficulty in walking and moving with these changes, the elderly must adapt to the surrounding environment. This is what triggers low back pain in the elderly. Pain can cause sleep disturbances, depression, anorexia, weight loss, fatigue, and isolation from social life (Rizqi AS \& Putra YW,2021)

\section{CONCLUSION}

The elderly have a high risk of musculoskeletal complaints, namely:

1. The higher the age of the elderly, the higher the risk of musculoskeletal complaints

2. Females are at a higher risk of musculoskeletal complaints than males

\section{REFERENCES}

Bayu, W. I., Destriana, D., Victorian, A. R., Yusfi, H., \& Solahuddin, S. (2021). Fitness Level Effect On The Grade-Point Average Of Physical Education Major Students. Halaman Olahraga Nusantara (Jurnal Ilmu Keolahragaan), 4(2), 180-191.

Haetami, M., \& Triansyah, A. (2021). The Effect Of Massage and Active 
Streching on Speeding up Blood Lactic Acid Recovery. Halaman Olahraga Nusantara (Jurnal Ilmu Keolahragaan), 4(2), 326-338.

Kurnia, R.(2019).Pengaruh Senam Terhadap Keluhan Muskuloskeletal Pada Lan sia.Interest: Jurnal Ilmu Kesehatan, 8(2), 137-140

Leni, A. S. M. (2020). Deteksi Dini Penyakit pada Lansia di Era Pandemic Covid19. Physio Journal, 1(1).

Livana, P. H., Suwoso, R. H., Febrianto, T., Kushindarto, D., \& Aziz, F. (2020). Dampak pandemi COVID-19bagi perekonomian masyarakat desa. Indo nesian Journal of Nursing and Health Sciences, 1(1), 37-48.

Mayasari, D. (2016). Ergonomi sebagai Upaya Pencegahan Musculoskeletal Dis orders pada Pekerja. Jurnal Kedokteran dan Kesehatan Universitas Lampung, 1(2), 369-379.

Nasution, N. H., \& Hidayah, A. (2021). Gambaran Pengetahuan Masyarakat Tentang Pencegahan Covid-19 Di Kecamatan Padangsidimpuan Batunadua, Kota Padangsidimpuan. Jurnal Kesehatan Ilmiah Indonesia (Indonesian Health Scientific Journal), 6(1), 107-114.

Nurmidin, M. F., Fatimawali, F., \& Posangi, J. (2020). Pengaruh Pandemi Covid19 Terhadap Aktivitas Fisik dan Penerapan Prinsip Gizi Seimbang Pada Mahasiswa Pascasarjana. Indonesian Journal of Public Health and Community Medicine, 1(4),28-32.

Putra, Y. W., \& Rizqi, A. S. (2020). Pelayanan Fisioterapi Untuk Meningkatkan Kapasitas Fisik Masyarakat. Al-Khidmat, 3(2), 9-14.

Rizqi, A. S., \& Putra, Y. W. (2020). Deteksi Dini Daya Tahan Jantung Paru Pada Mahasiswa. MOTORIK Jurnal Ilmu Kesehatan, 15(2), 52-54.

Rizqi, A. S., \& Putra, Y. W. (2021). Penyuluhan Kesehatan Penanganan Nyeri Punggung Bawah (Low Back Pain) di Krakitan Bayat Klaten. Jurnal Pengabdian Magister Pendidikan IPA, 4(3).

Thomas, P., Baldwin, C., Bissett, B., Boden, I., Gosselink, R., Granger, C. L., ... $\&$ van der Lee, L. (2020). Physiotherapy management for COVID-19 in the acute hospital setting: clinical practice recommendations. Journal of Physiotherapy, 66(2), 73-82.

Wahyono, Y., \& Saloko, E. (2014). Pengaruh Workplace Exercise terhadap Kelu han Muskuloskeletal pada Pekerja di bagian Sewing CV. Cahyo Nu groho Jati (CNJ) Sukoharjo. Interest: Jurnal Ilmu Kesehatan, 3(2).

Widyaningrum, N., Djayanti Putri, Y., \& Wilopo. (2020). Gambaran penerapan physical distancing sebagai upaya menekan persebaran Covid-19di pro vinsi daerah istimewa Yogyakarta. NUSANTARA : Jurnal Ilmu Pengeta huan Sosial, 7(2), 470-481. 


\section{OLAHRAGA}

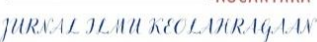

Jendral A. Yani Street Lorong Gotong Royong 9/10 Ulu

email jurnal: jurnalhon@univpgri-palembang.ac.id situs web: http://www.univpgri-palembang.ac.id

Wahidah, I., Athallah, R., Hartono, N. F. S., Rafqie, M. C. A., \& Septiadi, M. A. (2020). Pandemik COVID-19: Analisis Perencanaan Pemerintah dan Masyarakat dalam Berbagai Upaya Pencegahan. Jurnal Manajemen dan Organisasi, 11(3), 179-188. 